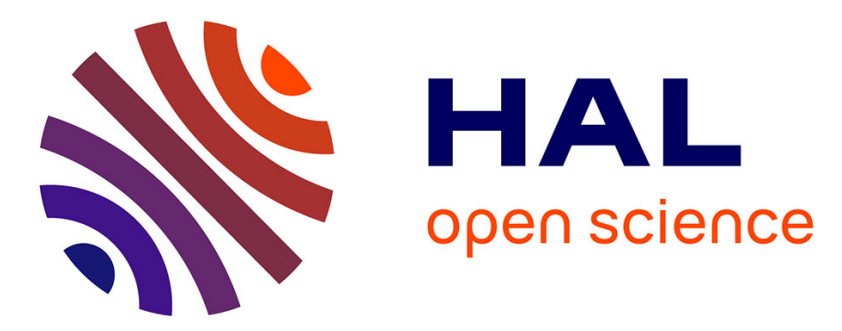

\title{
ELIMINATION OF TWINNING IN MOLECULAR BEAM EPITAXY OF GaAs/Si and GaAs/INSULATOR
}

C. Fontaine, J. Castagne, Eléna Bedel-Pereira, A. Muñoz-Yagüe

\section{To cite this version:}

C. Fontaine, J. Castagne, Eléna Bedel-Pereira, A. Muñoz-Yagüe. ELIMINATION OF TWINNING IN MOLECULAR BEAM EPITAXY OF GaAs/Si and GaAs/INSULATOR. Journal de Physique Colloques, 1988, 49 (C4), pp.C4-697-C4-700. 10.1051/jphyscol:19884146 . jpa-00227884

\section{HAL Id: jpa-00227884 https://hal.science/jpa-00227884}

Submitted on 1 Jan 1988

HAL is a multi-disciplinary open access archive for the deposit and dissemination of scientific research documents, whether they are published or not. The documents may come from teaching and research institutions in France or abroad, or from public or private research centers.
L'archive ouverte pluridisciplinaire HAL, est destinée au dépôt et à la diffusion de documents scientifiques de niveau recherche, publiés ou non, émanant des établissements d'enseignement et de recherche français ou étrangers, des laboratoires publics ou privés. 


\title{
ELIMINATION OF TWINNING IN MOLECULAR BEAM EPITAXY OF GaAs/SI and GaAs/INSULATOR
}

\author{
C. Fontaine, J. CASTAGNe, E. BEDEL and A. MUNOZ-yague \\ Laboratoire d'Automatique et d'Analyse des Systèmes du CNRS, 7, Av. du \\ Colonel Roche, F-31077 Toulouse cedex, France
}

\begin{abstract}
Résumé - Nous présentons une étude de la nucléation de GaAs sur des surfaces (100) de $\mathrm{Si}$ et de $(\mathrm{Ca}, \mathrm{Sr}) \mathrm{F}_{2}$ montrant qu'une crolssance $2 \mathrm{D}$ peut être obtenue pour des dépóts très fins $\left(15 \mathrm{~A}^{\circ}\right)$ réalisés à basse température $\left(25-100^{\circ} \mathrm{C}\right)$. La stoechlométrie du dépôt est obtenue en augmentant la température jusqu'a $300-400^{\circ} \mathrm{C}$ ce qui conduit, en même temps, à la cristallisation de la couche. Le diagramme de diffraction électronique met en évidence l'absence de micromacles et l'obtention d'une surface plane au niveau atomique. La procédure proposée ouvre la vole à l'utilisation de techniques basse température pour l'élaboration de structures co-intégrées associant GaAs et $\mathrm{Si}$.

Abstract - We present a study of GaAs nucleation on $S i$ and $(\mathrm{Ca}, \mathrm{Sr}) F_{2}$ (100) surfaces which shows that a $2 \mathrm{D}$ growth can be achieved for very thin $\left(15 \mathrm{~A}^{\circ}\right)$ deposits obtained at low temperature $\left(25-100^{\circ} \mathrm{C}\right)$. Raising the temperature to $300-400^{\circ} \mathrm{C}$ leads to a stoichiometric and monocrystalline layer. Electron diffraction shows a diagram without twin spots and a surface devoid of noticeable roughness. The proposed procedure paves the way for the subsequent use of low temperature techniques aimed at the fabrication of co-integrated structures associating GaAs and $\mathrm{Si}$.
\end{abstract}

\section{1 - INTRODUCTION}

Gallium Arsenide epitaxy on Silicon substrates has reveived considerable attention over the last years, and the quality of the layers has been dramatically improved. Although successful demonstration devices have been reported the properties of the GaAs heteroepitaxial layers have still to be improved. This implies the reduction or elimination of the crystalline defects - twins and dislocations-present in these layers, specially near the layer-substrate interface. Even if post-growth annealing (in or ex situ) can be used to overcome this problem, specific growth procedures preventing defect formation during the growth should be preferred.

In addition, low temperature processes have to be developed to reduce the interdiffusion problems at the GaAs-Si interface (namely Si diffusion into GaAs) and to permit fabrication of co-integrated structures.

Among the mechanisms giving rise to the aforementioned crystal defects, the threedimensional mode (3D-growth) of the heteroepitaxial GaAs nucleation is often invoked. Here, a growth technique is proposed which favors layer-by-layer nucleation (2D-growth) of the GaAs heteroepitaxial layer.

As the technique used for the $S i$ substrate preparation requires heating of the substrate to only $600^{\circ} \mathrm{C}$ for 10 minutes and as the proposed nucleation procedure works at $400^{\circ} \mathrm{C}$, both steps offer promising prospects for low temperature processing in GaAs/Si molecular beam epitaxy (MBE). Finally, the results presented show that extended defects like twins are eliminated in the early stage of growth.

\section{2 - EXPERIMENTAL}

An ultra-high vacuum MBE system provided with two main chambers, an Auger electron spectrometer (AES) and an electron diffractometer (RHEED), was used in this study.

The Si substrates were $(100), 2^{\circ}$ misoriented towards 1011$]$. The preparation of the substrates has been described elsewhere [1]; it is briefly recalled here as part of the low temperature process : the substrates, with a protective layer of thermally grown $\mathrm{SiO}_{2}$, were first etched using an HF : ethanol solution to remove this oxide just before loading into the vacuum chamber. AES reveals that, at this point, the surface is devoid of any traces of $O$ or $C$ contamination. RHEED shows a streaky pattern. In the second step, this surface is exposed to low $S i$ atomic flux provided by the effusion cell used for $n$-type doping of GaAs. This flux is not sufficient to grow a $\mathrm{Si}$ buffer layer, but allows the 
reconstruction of the Si surface ; indeed, after 10 minutes at $600^{\circ} \mathrm{C}$, the RHEED diagram consists of sharp and intense lines with $a(2 \times 2)$ reconstruction (figure 1 a) that is interpreted as a mixture of (100) terraces with $(1 \times 2)$ and $(2 \times 1)$ reconstructions. It has been shown that such a Si surface, even with monoatomic steps, allows GaAs to be grown without antiphase defects [2].

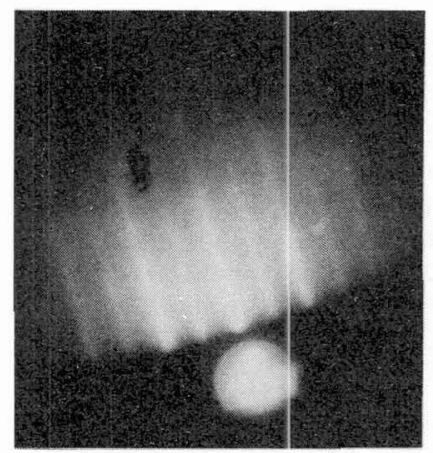

a)

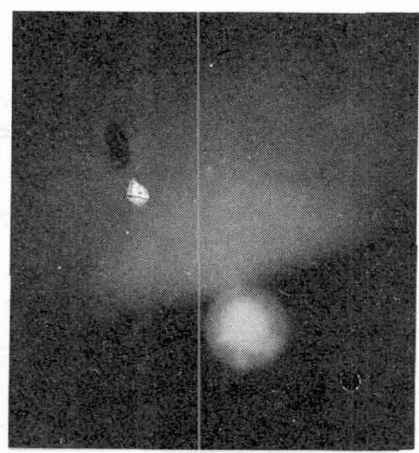

b)

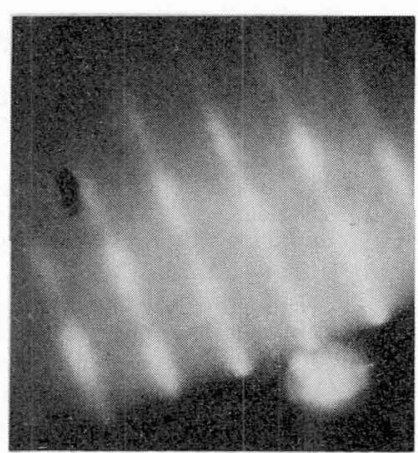

c)

Fig. 1 - RHEED diagram obtained for the [011] azimuth on a) the cleaned si surface, b) on the $15 \mathrm{~A}^{\circ}$ thick amorphous layer grown at low temperature and $c$ ) after annealing of this layer at $400^{\circ} \mathrm{C}$.

\section{3 - RESULTS AND DISCUSSION}

The initial step of: GaAs/Si MBE epitaxy generally follows the procedure proposed by Wang [3], which consists in the growth of a $200 \mathrm{~A}^{\circ}$ thick layer at moderate temperature (300$400^{\circ} \mathrm{C}$ ) and a growth rate $(0.1 \mu \mathrm{m} / \mathrm{h})$. When this procedure is applied, a $3-\mathrm{D}$ nucleation is observed using AES or RHEED : GaAs islands nucleate and grow to finally coalesce for a deposited mean thickness of about $200 \mathrm{~A}^{\circ}$. The RHEED diagrams are spotty, denoting surface roughness, and frequently reveal twin spots which are eliminated later on, when the growth is continued at higher temperatures $\left(580^{\circ} \mathrm{G}\right)$.

To avoid defect creation at the coalescence stage, a $2 \mathrm{D}$ nucleation should be preferred. In addition, it would produce a much smoother surface. A 3D nucleation mechanism can be deviated towards a 2D process by lowering the growth temperature : the reduction of the diffusion length of the impinging atoms favors this type of nucleation. The problem, which then arises for GaAs, is that the deposit is no longer monocrystalline and stoichiometric. This is indeed observed experimentally. Figure $1 \mathrm{~b}$ shows that when a $15 \mathrm{~A}^{\circ}$ thick layer of GaAs is grown on a $\mathrm{Si}$ surface at low temperature (between 25 and $100^{\circ} \mathrm{C}$ ) the deposit is amorphous, the RHEED diagram showing a diffuse halo. Auger analysis shows an excess As concentration in the layer due to the increase of the sticking coefficient of the As molecules evaporated from the effusion cell.

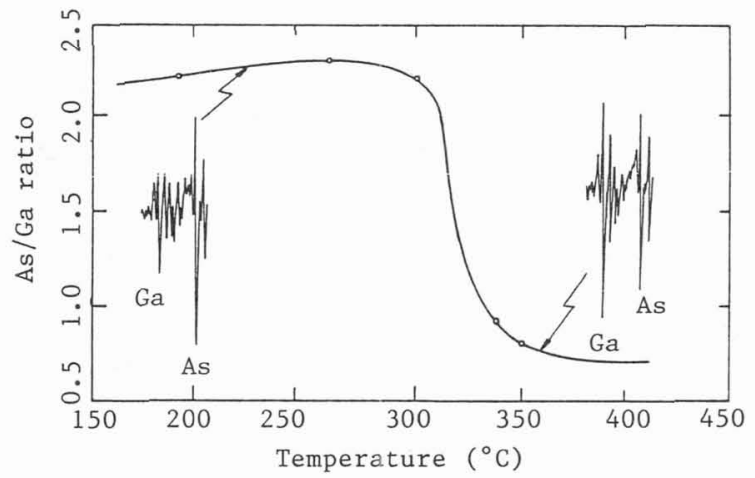

Fig, 2 - Variation of the Auger signal ratio, As ( $1210 \mathrm{ev}) / \mathrm{Ga}(1065 \mathrm{eV})$, for a deposit grown at low temperature when the temperature is raised, evidencing the restoration of the layer stoichiometry during the thermal process. 
This can be rapidly improved by a moderate thermal treatment : between $300^{\circ}$ and $400^{\circ} \mathrm{C}$, the stoichiometry is restored by evaporation of the excess As (figure 2), and simultaneously, a monocrystalline layer is obtained: The RHEED diagram is a streaky pattern, with an incipient reconstruction devoid of twin spots (figure 1c). This result, which has been obtained systematically, demonstrates that the Si substrate is covered up by a very thin GaAs layer with a flat single oriented surface. Usually, such a RHEED dfagram is obtained, using standard procedures, after the growth of much thicker $\left(2000 \mathrm{~A}^{\circ}\right)$ layers.

The proposed procedure also applies to the growth of GaAs/(Ca, Sr) F $/ \mathrm{Si}$ structures [4]. The fluoride layer can be used to reduce the lattice mismatch between $S i$ and GaAs, also offering an insulating layer between the semiconductors that could be useful in some applications. Here also, after heating at $400^{\circ} \mathrm{C}$ the $15 \mathrm{~A}^{\circ}$ thick deposit of GaAs on a $(\mathrm{Ca}, \mathrm{Sr}) \mathrm{F}_{2}$ layer $\left(10^{3} \mathrm{~A}^{\circ}\right)$ grown on a $\mathrm{Si}^{\circ}$ substrate, the resulting layer presents a good crystallinity, without surface roughness (figure 3 ).

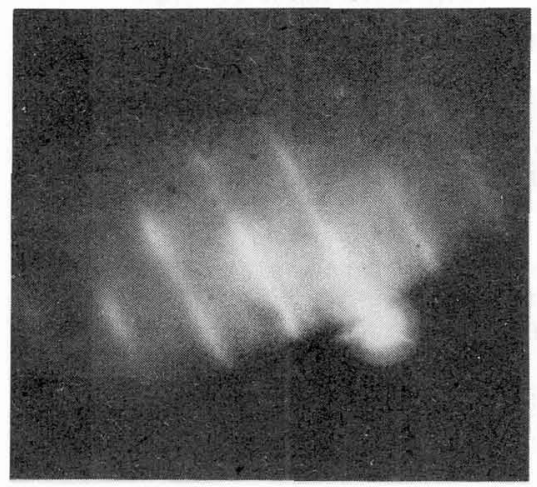

Fig. 3 - <011> RHEED diagram obtained on a $15 \mathrm{~A}^{\circ}$ thick amorphous GaAs deposit on $(\mathrm{Ca}, \mathrm{Sr}) \mathrm{F}_{2} /$ Si (100) after its annealing at $400^{\circ} \mathrm{C}$.

The lack of twins in thicker layers grown using this nucleation procedure has also been verified using Raman Spectrometry. It has been shown [5] that, under adequate experimental conditions, the twinned volume in a GaAs (100) layer can be measured from the Lo (allowed)/ To (forbidden) phonon ratio. As shown in figure 4 the Raman spectra obtained under those conditions on a GaAs/Si layer exhibit no TO phonon peak, confirming thus that no misoriented twinned regions exist in the GaAs layer.

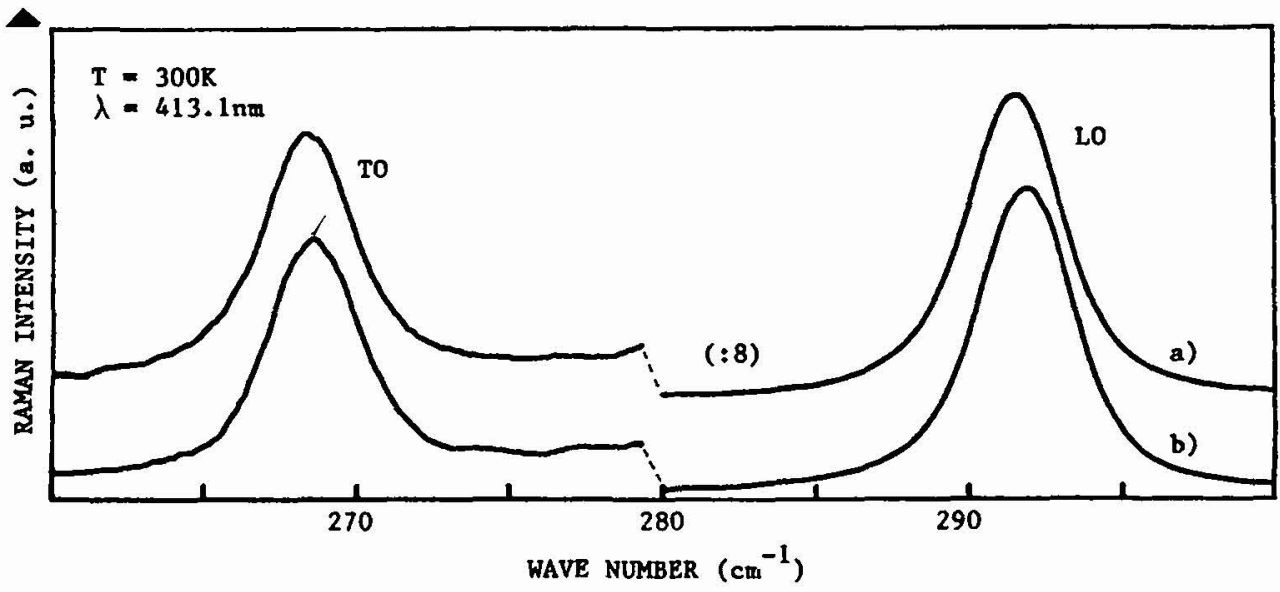

Fig. 4 - Raman spectra obtained on a) a $1 \mu \mathrm{m}$ thick GaAs layer grown on $\mathrm{Si}$ (100) with the proposed procedure and b) a reference homoepitaxial GaAs layer : the peak shifts evidence the presence of thermal stress in the heteroepitaxial layer. The TO/LO amplitude ratio is the same for both samples. 


\section{4 - CONCLUSION}

We have presented procedures for $S i$ surface preparation and for GaAs heteroepitaxial nucleation using MBE which lead to a good crystalline material and improved surface morphology.

The advantages of employing an Initial deposit ( $15 \mathrm{~A}^{\circ}$ thick) at room temperature, stolchiometry and crystallinity of which are restored by a moderate thermal treatment $\left(400^{\circ} \mathrm{C}\right)$, have been demonstrated for GaAs growth on $\mathrm{Si}$ and on $(\mathrm{Ca}, \mathrm{Sr}) \mathrm{F}_{2}$. The proposed techniques, coupled with other means of reducing both the dislocation density and the growth temperature, could be useful in the future growth of co-integrated GaAs-Si structures.

\section{ACKNOWLEDGEMENTS}

R. CARLES and G. LANDA axe acknowledged for their kind collaboration on Raman spectroscopy .

\section{REFERENCES}

/1/ Castagné, J., Fontaine, C., Bedel, E. and Munoz-Yague, A., J. Appl. Phys. to be published in June 1988 .

/2/ Kawanami, H., Hatayama, A., Nagai, K. and Hayashi, Y., Jpn. J. Appl. Phys. 266 (1987) L173.

/3/ Wang, W.I., Appl. Phys. Lett. 44 (1984).

1.4/ Munoz-Yague, A. and Fontaine, C., Advances in semiconductors and superconductors : Physics and device Applications, S.P.I.E., New-Port Beach, USA, (March 1988).

15/ Landa, G., Carles, R., Renucci, J.B., Fontaine, C., Bede1, E. and Munoz-Yague, A., J.Appl. Phys. 60 (1986) 1025 . 